\title{
A Widespread and Distinctive Form of Amphipod Intersexuality Not Induced by Known Feminising Parasites
}

\author{
S. Short ${ }^{\mathrm{a}}$ G. Yang ${ }^{\mathrm{a}, \mathrm{b}} \quad$ P. Kille ${ }^{\mathrm{c}} \quad$ A.T. Ford ${ }^{\mathrm{a}}$ \\ a Institute of Marine Sciences, School of Biological Sciences, University of Portsmouth, Portsmouth, \\ ${ }^{b}$ Environmental Research Institute, North Highland College, UHI Millennium Institute, Thurso, and 'School of \\ Biosciences, University of Wales Cardiff, Cardiff, UK
}

\section{Key Words}

Amphipod $\cdot$ Echinogammarus marinus $\cdot$ Feminising

parasites $\cdot$ Intersex $\cdot$ Ovotestis

\begin{abstract}
Intersexuality occurs in a diverse range of animals, and its study offers insights into basic reproductive biology. Investigations in amphipods suggest intersexuality results from incomplete feminisation caused by sex-distorting parasites. It has also been noted that 2 intersex phenotypes occur in males of the amphipod Echinogammarus marinus, an external phenotype, in which males possess rudimentary brood plates, and an internal phenotype, in which only an ovotestis is present. This study examines the relationship between these phenotypes and finds their prevalences are independent. In addition, a cross-species microarray reveals the testicular transcriptomes of the intersex phenotypes are distinct from that of normal males and, most crucially, each other. Furthermore, the internal intersex phenotype, unlike the external phenotype, shows no correlation with infection by known feminising parasites. These findings suggest the male intersex phenotypes should not be considered stages on a single spectrum of intersexuality. Rather, they support the hypothesis that internal and external intersexuality are divergent phenotypes with separate causal mechanisms
\end{abstract}

\section{KARGER}

Fax +4161306 1234

E-Mail karger@karger.ch

www.karger.com
(C) 2012 S. Karger AG, Basel

$1661-5425 / 12 / 0066-0320 \$ 38.00 / 0$

Accessible online at:

www.karger.com/sxd and point to the existence of a distinct and geographically widespread form of amphipod intersexuality caused by an unknown factor.

Copyright $\odot 2012$ S. Karger AG, Basel

\section{Introduction}

Intersex is an atypical sexual phenotype whereby both male and female secondary sex characteristics occur on the same individual [Ford, 2012]. Intersexuality and its associated reproductive costs occur in amphipods of both sexes [Ford et al., 2003; Ford and Fernandes, 2005; Yang et al., 2008], and it was recently noted that males of the amphipod Echinogammarus marinus present an external and internal intersex phenotype [Ford et al., 2005; Yang et al., 2008]. External intersex males possess rudimental brood plates, a feature normally associated with females, and sometimes exhibit an ovotestis (consisting of a pronounced oviduct-like structure on the testes as described in Ford et al. [2005]), with internal intersex males possessing an ovotestis, but never presenting brood plates [Yang et al., 2008, 2011].

External intersex males are significantly more likely than normal males to be infected with feminising microsporidian and paramyxean parasites [Ford et al., 2006; 
Short et al., 2012], leading to the hypothesis that both male intersex phenotypes are stages on a single spectrum of intersexuality resulting from parasite-induced incomplete feminisation [Ford et al., 2008].

Although elegant, there is recent evidence to suggest the situation is more complex. For example, while external intersex males sampled from a site in Scotland (Inverkeithing) present high coinfection (85-86\%) with feminising parasites, normal males present very low infection levels (2-3\%) [Ford et al., 2006; Short et al., 2012]. However, despite the low infection levels, examination of a range of morphometric characters (including multiple coxal plate measurements and gnathopod, eye and head length) of Inverkeithing animals suggest normal males still present a demasculinised phenotype [Ford et al., 2004]. If male intersexuality results from parasite-mediated incomplete feminisation, it is unlikely the low infection level can account for the observed demasculinisation of normal males. Indeed, Ford et al. [2004] found that normal males from polluted sites (including Inverkeithing) more closely resemble external intersex males than they do normal males from reference sites and suggested pollutants might alter normal androgenic gland function. Furthermore, external intersex males often lack an ovotestis, while males presenting a well-developed ovotestis often lack brood plates [Ford et al., 2005; Yang et al., 2008], with internal and external intersex characteristics being rarely seen on the same specimen at some sites [Yang et al., 2011]. This suggests that internal intersexuality is not a prerequisite to changes in external morphology or vice versa.

This study investigates the relationship between the male sexual phenotypes. We examine current and previously published data and find the levels of the 2 intersex phenotypes are independent. We also use a microarray to find the intersex phenotypes possess distinct testicular transcriptomic profiles. Finally, we establish that, unlike external intersexuality, internal intersexuality is not associated with infection by any feminising parasite known to infect amphipods [Cordaux et al., 2001; Short et al., 2012].

\section{Material and Methods}

\section{Sampling}

E. marinus males were collected beneath seaweeds in the intertidal zone of Inverkeithing, Scotland (56 $6^{\circ} 38^{\prime \prime} \mathrm{N}, 3^{\circ} 23^{\prime} 37^{\prime \prime}$ $\mathrm{W})$ before being anaesthetised and categorised as normal, external intersex (possessing brood plates) or internal intersex (only possessing an ovotestis) males. These data were combined with previous studies from around the UK [Ford et al., 2006; Yang et al., 2008, 2011] to analyse phenotype prevalences between 2002 and 2010 .

\section{Microarray}

This study utilised a microarray that efficiently cross-hybridises with E. marinus sequences [Ford et al., 2008] and was developed using Gammarus pulex EST libraries representing a range of developmental stages and moult-cycle phases for both sexes, together with sex-specific subtractive suppression hybridisation libraries. To construct the target libraries, the testes of 25 individuals from each phenotype were dissected, with the testes from 5 males being pooled to give 5 replicates for each phenotype. Total RNA was isolated using Tri-reagent (Ambion), and the quality and quantity of RNA samples were assessed using agarose gel electrophoresis and spectrophotometry (Nanodrop ND-1000), respectively. The libraries were then created using $2 \mu \mathrm{g}$ of RNA for each sample before the array hybridisation, fluorescence quantification, validation, and normalisation were performed as previously described [Ford et al., 2008]. An ANOVA analysis was conducted on the array data generating a list of genes presenting significantly different expression $(\mathrm{p}<0.05)$ amongst the 3 phenotypes and a principal component analysis (PCA) was used to identify differential gene expression patterns amongst the phenotypes.

\section{Parasite Screening}

Genomic DNA was isolated from internal intersex males and quantified via spectrophotometry (NanoDrop ND-1000). The DNA quality was confirmed by PCR amplification of a host gene as previously described [Yang et al., 2011; Short et al., 2012]. The samples were screened using previously described PCR assays for the presence of general microsporidia, the microsporidian Dictyocoela duebenum [Yang et al., 2011], paramyxean parasites [Short et al., 2012], and Wolbachia bacteria [Werren and Windsor, 2000; Cordaux et al., 2001].

\section{Results}

\section{Intersex Phenotype Levels Appear Independent}

An analysis was conducted on the prevalence of sexual phenotypes presented by E. marinus males at various sites between 2002 and 2010. The results (table 1) indicate that the levels of internal and external intersex phenotypes are independent, with no significant correlation between the levels of intersex phenotypes. (Pearson's correlation, $\mathrm{p}>$ $0.05)$. Levels of external intersex at Inverkeithing are higher than levels of internal intersex in both 2007 and 2010, with no significant difference between the phenotype levels $\left(\chi^{2}=0.754, d f=2, p=0.686\right)$. In contrast, males from Thurso, Scotland, and Portsmouth Harbour, England, present higher levels of internal intersex, with a $\chi^{2}$ test revealing significant differences $\left(\chi^{2}=40.1, \mathrm{df}=6, \mathrm{p}<0.01\right)$ between the phenotype prevalences at the 4 sites. 
Table 1. Prevalences of the 3 male intersex phenotypes presented by E. marinus

\begin{tabular}{|c|c|c|c|c|c|c|c|c|}
\hline \multirow[t]{2}{*}{ Site } & \multirow[t]{2}{*}{ Season } & \multicolumn{2}{|l|}{ NM } & \multicolumn{2}{|l|}{ EIM } & \multicolumn{2}{|c|}{ IIM } & \multirow[t]{2}{*}{ Reference } \\
\hline & & $\mathrm{n}$ & $\%$ & $\mathrm{n}$ & $\%$ & $\mathrm{n}$ & $\%$ & \\
\hline $\begin{array}{l}\text { Inverkeithing } \\
\text { (Scotland) }\end{array}$ & spring 2002 & 67 & 91.8 & 6 & 8.2 & $\mathrm{nr}$ & $\mathrm{nr}$ & $\begin{array}{l}\text { Ford et al. } \\
(2006)\end{array}$ \\
\hline $\begin{array}{l}\text { Inverkeithing } \\
\text { (Scotland) }\end{array}$ & summer 2002 & 220 & 91.3 & 21 & 8.7 & $\mathrm{nr}$ & $\mathrm{nr}$ & $\begin{array}{l}\text { Ford et al. } \\
(2006)\end{array}$ \\
\hline $\begin{array}{l}\text { Inverkeithing } \\
\text { (Scotland) }\end{array}$ & winter 2002 & 153 & 93.9 & 10 & 6.1 & $\mathrm{nr}$ & $\mathrm{nr}$ & $\begin{array}{l}\text { Ford et al. } \\
(2006)\end{array}$ \\
\hline $\begin{array}{l}\text { Inverkeithing } \\
\text { (Scotland) }\end{array}$ & spring 2003 & 210 & 94.6 & 12 & 5.4 & $\mathrm{nr}$ & $\mathrm{nr}$ & $\begin{array}{l}\text { Ford et al. } \\
(2006)\end{array}$ \\
\hline $\begin{array}{l}\text { Inverkeithing } \\
\text { (Scotland) }\end{array}$ & spring 2007 & 47 & 70.1 & 11 & 16.4 & 9 & 13.4 & $\begin{array}{l}\text { Yang et al. } \\
(2008)\end{array}$ \\
\hline $\begin{array}{l}\text { Loch Fleet } \\
\text { (Scotland) }\end{array}$ & spring 2007 & 76 & 93.8 & 2 & 2.5 & 3 & 3.7 & $\begin{array}{l}\text { Yang et al. } \\
(2008)\end{array}$ \\
\hline $\begin{array}{l}\text { Thurso } \\
\text { (Scotland) }\end{array}$ & spring 2007 & 94 & 82.5 & 5 & 4.4 & 15 & 13.2 & $\begin{array}{l}\text { Yang et al. } \\
(2008)\end{array}$ \\
\hline $\begin{array}{l}\text { Portsmouth } \\
\text { Harbour (England) }\end{array}$ & summer 2009 & 260 & 81.3 & $21^{*}$ & 6.6 & 39 & 12.2 & $\begin{array}{l}\text { Yang et al. } \\
\text { (2011) }\end{array}$ \\
\hline $\begin{array}{l}\text { Inverkeithing } \\
\text { (Scotland) }\end{array}$ & summer 2010 & 67 & 66.3 & $22^{* *}$ & 21.8 & 12 & 11.9 & this study \\
\hline
\end{tabular}

$\mathrm{NM}=$ Normal males; EIM = external intersex males; IIM = internal intersex males; $\mathrm{nr}=$ not recorded.

${ }^{*} 8.3 \%$ of these males also present an ovotestis, ${ }^{* *} 45.5 \%$ of these males also present an ovotestis.

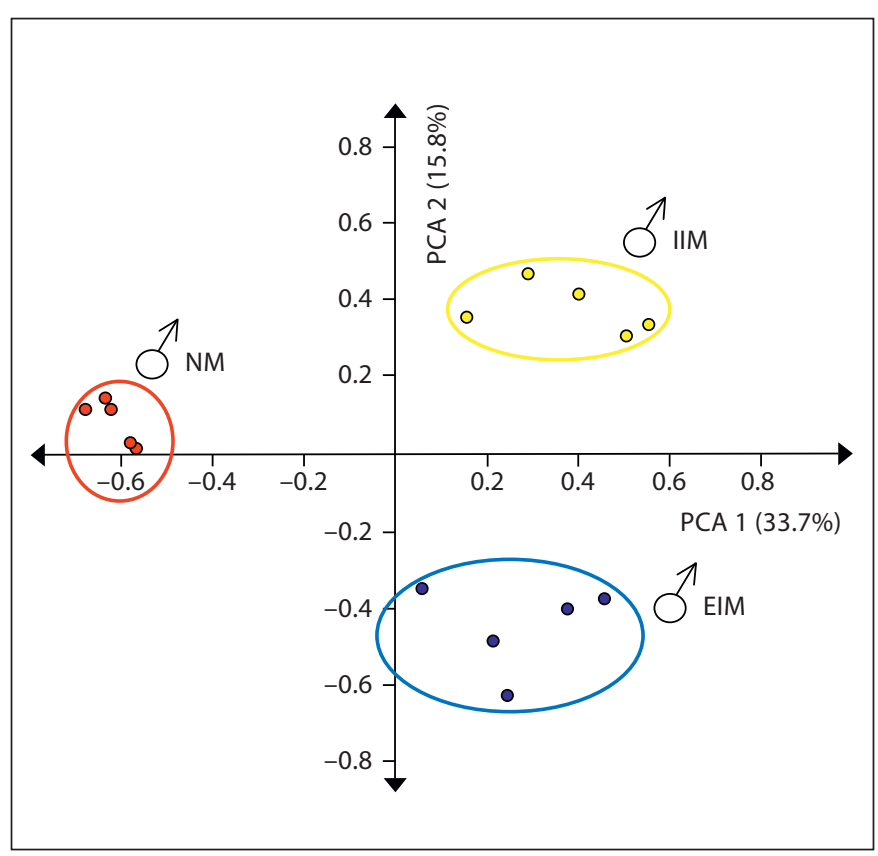

Fig. 1. A PCA analysis performed on the 349 EST list created by comparing gene expression levels (ANOVA $>1.4$-fold expression, $\mathrm{p}<0.05)$ in the testes of the 3 male sexual phenotypes of $E$. marinus. The 15 samples differentiate into 3 patches formed by the 5 replicates of the same phenotype. $\mathrm{NM}=$ Normal males; EIM $=$ external intersex males; IIM = internal intersex males.

\section{Male Sexual Phenotypes Have Distinct \\ Transcriptomes}

To investigate the male E. marinus phenotypes at the transcriptomic level, 5 target libraries (each representing testes from 5 pooled males) from the 3 sexual phenotypes were hybridised to a cross-species microarray that demonstrated consistent hybridisation (83\% significant signal above background). A volcano plot analysis performed on the data $(>1$-fold expression; $p<0.05)$ created lists of 453 and 351 ESTs differing significantly between normal, internal and external intersex males, respectively, with 87 ESTs being common to both lists. A further comparison of the 2 intersex phenotypes revealed 230 ESTs differing significantly between groups. A subsequent ANOVA analysis indicates 349 ESTs (representing a total of 223 gene objects) presenting significantly different expression $(>1.4$-fold expression; $\mathrm{p}<0.05$ ) between the 3 sexual phenotypes. Following annotation (Blast2GO; E-value cutoff: e-5) $21.2 \%$ of the ESTs (74/349) were assigned a GO term, however, no obvious bias was observed in the distribution of gene function when compared to all 13,383 ESTs on the microarray. This was also found for 2-way comparisons of the sexual phenotypes. A PCA was performed on the 349 EST list and the 15 samples clearly differentiate into 3 patches formed by the 5 replicates (fig. 1). 
The greatest variation (33.7\%) is seen along the $\mathrm{x}$-axis, separating the testes of normal males from the 2 male intersex phenotypes, while less variation (15.8\%) separated all 3 groups along the $y$-axis.

\section{Internal Intersex Phenotype Does Not Correlate with}

Feminising Parasite Infection

Internal intersex males from Inverkeithing were screened for the presence of general microsporidia and $D$. duebenum, the microsporidian species that dominates this population [Short et al., 2012]. Subsequent screening was performed for paramyxean parasites and all strains of Wolbachia bacteria. Despite successful controls, no internal intersex male specimens were infected with any microsporidia or Wolbachia, with only one specimen infected with a paramyxean (table 2). Fisher's exact test ( 2 tailed) reveals there is no significant difference in the level of infection for all parasites between normal and internal intersex males $(\mathrm{p}=0.39)$. However, there is a significant difference in the level of $D$. duebenum and paramyxean infection between external and internal intersex males $(p<0.0001$ Fisher's exact test, 2 tailed).

\section{Discussion}

It had been suggested that the internal and external intersex phenotypes of male E. marinus represent different positions on a single spectrum of intersexuality [Ford et al., 2008]. However, comparison of intersex phenotype prevalences supports the hypothesis that the intersex phenotypes are independent, with PCA analysis of microarray data providing evidence that the intersex testicular transcriptomes are distinct. The PCA analysis also indicates that the intersex transcriptomes are more similar to each other than either is to that of a normal male, suggesting that if the intersex phenotypes have distinct causal mechanisms, they likely share altered molecular pathways in common. Furthermore, in contrast to external intersex males [Short et al., 2012], internal intersex males present no correlation with parasite infection, suggesting that the transcriptomic separation between the normal, internal and external intersex males is not due to the expression of immune genes triggered by infection. Unfortunately, annotation of the sequences on the microarray has proved difficult, probably due the distant evolutionary relationship between E. marinus and Drosophila melanogaster and the fast evolution of reproductive genes [Ellegren and Parsch, 2007].

Nonparasite-Induced Amphipod Intersexuality
Table 2. Screen for the presence of the D. duebenum, Paramyxea and Wolbachia parasite genes in E. marinus males presenting a range of sexual phenotypes

\begin{tabular}{|c|c|c|c|c|c|c|c|c|c|}
\hline \multirow[t]{3}{*}{ Parasite species } & \multirow{2}{*}{\multicolumn{3}{|c|}{$\frac{\mathrm{NM}^{*}}{\text { infection }}$}} & \multirow{2}{*}{\multicolumn{3}{|c|}{$\frac{\text { EIM }^{*}}{\text { infection }}$}} & \multirow{2}{*}{\multicolumn{3}{|c|}{$\frac{\text { IIM }}{\text { infection }}$}} \\
\hline & & & & & & & & & \\
\hline & $\mathrm{y}$ & $\mathrm{n}$ & $\%$ & $\mathrm{y}$ & $\mathrm{n}$ & $\%$ & $\mathrm{y}$ & $\mathrm{n}$ & $\%$ \\
\hline D. duebenum & 1 & 66 & 1.5 & 19 & 3 & 86.4 & 0 & 12 & 0 \\
\hline Paramyxean sp. & 2 & 65 & 3 & 19 & 3 & 86.4 & 1 & 11 & 8.3 \\
\hline Wolbachia & 0 & 67 & 0 & 0 & 22 & 0 & 0 & 12 & 0 \\
\hline
\end{tabular}

* Previously published data [Short et al., 2012] presented to allow comparison with the IIM phenotype. NM = Normal males; $\mathrm{EIM}=$ external intersex males; IIM = internal intersex males; $\mathrm{y}=$ infected; $\mathrm{n}=$ uninfected.

Although the internal intersex specimens do not correlate with feminising parasite infection, they may be infected with a currently uncharacterised parasite. Additionally, the phenotype might result from an early infection that failed to establish but left an ovotestis as a developmental legacy. However, this hypothesis is weakened by findings showing that populations uninfected by feminising parasites possess high levels of internal intersexuality [Yang et al., 2011; Short et al., 2012]. It is known that $E$. marinus sex determination is influenced by day length [Guler et al., 2012] and a link between intersexuality and environmental sex determination in amphipods has been documented [Dunn et al., 1990, 1996]. It is possible that a particular set of conditions might result in increased internal intersexuality. However, this hypothesis is undermined by high internal intersex levels in Scotland and southern England, locations varying considerably in temperature and day-night length ratios.

Whatever the causal mechanism of the phenotype, it is tempting to speculate that it results from a delayed gonadal maturation. Juvenile amphipods have undifferentiated gonads and possess anlages of oviduct and vas deferens [Lockwood, 1968], with the oviduct-structure in normal males degenerating quickly after sexual differentiation [Ginsburger-Vogel, 1972a, b]. The internal intersex phenotype could be interpreted as a case of delayed degeneration, representing the extreme end on a spectrum of nonparasite-induced demasculinisation. This hypothesis is consistent with findings that morphometric characters of normal (uninfected) males from a polluted site presenting high levels of internal intersexuality more closely resemble those of the feminised (infected) exter-

Sex Dev 2012;6:320-324 
nal intersex males than they do normal males from less polluted sites [Ford et al., 2004]. If this phenotype does represent a fully grown but developmentally stalled animal, its further investigation at the molecular level promises insights into the poorly understood molecular basis of crustacean sexual development.

\section{Acknowledgements}

Both S.S. and G.Y. are supported by NERC, UK (NE-G0045871; MGF223; NBAF 479 \& 438) awarded to P.K. and A.T.F. Furthermore, G.Y. is also supported by the UHI Millennium Institute ARC Programme. We would like to thank Francis Jiggins and Fergal Waldron for the kind donation of Drosophila melanogaster strains infected with Wolbachia.

\section{References}

Cordaux R, Michel-Salzat A, Bouchon D: Wolbachia infection in crustaceans: novel hosts and potential routes for horizontal transmission. J Evol Biol 14:237-243 (2001).

Dunn AM, Adams J, Smith JE: Intersexes in a shrimp: a possible disadvantage of environmental sex determination. Evolution 44: 1875-1878 (1990).

-Dunn AM, McCabez J, Adams J: Intersexuality in Gammarus duebenii (Amphipoda), a cost incurred in populations with environmental sex determination? Crustaceana 69:313-320 (1996).

Ellegren H, Parsch J: The evolution of sex-biased genes and sex-biased gene expression. Nat Rev Genet 8:689-698 (2007).

Ford AT: Intersexuality in Crustacea: an environmental issue? Aquat Toxicol 108:125-129 (2012).

Ford AT, Fernandes TF: Notes on the occurrence of intersex in amphipods. Hydrobiologia 548:313-318 (2005).

Ford AT, Fernandes TF, Rider SA, Read PA, Robinson CD, Davies IM: Reproduction in the amphipod, Echinogammarus marinus: a comparison between normal and intersex specimens. J Mar Biol Assoc UK 83:937-940 (2003).
Ford AT, Fernandes TF, Rider SA, Read PA, Robinson CD, Davies IM: Endocrine disruption in a marine amphipod? Field observations of intersexuality and de-masculinisation. Mar Environ Res 58:169-173 (2004).

-Ford AT, Rodgers-Gray TP, Davies IM, Dunn AM, Read PA, et al: Abnormal gonadal morphology in intersex, Echinogammarus marinus (Amphipoda): a possible cause of reduced fecundity? Mar Biol 147:913-918 (2005).

Ford AT, Fernandes TF, Robinson CD, Davies IM, Read PA: Can industrial pollution cause intersexuality in the amphipod, Echinogammarus marinus? Mar Pollut Bull 53:100-106 (2006).

Ford AT, Sambles C, Kille P: Intersexuality in crustaceans: genetic, individual and population level effects. Mar Environ Res 66:146148 (2008).

Ginsburger-Vogel T: Démontration expérimentale de l'homogamétie femelle chez Orchestia cavimana (Heller) (Crustacés Amphipodes Talitridae). CR Acad Sci Hebd Seances Acad Sci D 275:3606-3609 (1972a).

Ginsburger-Vogel T: Inversion of Orchestia gammarella Pallas (crustacea amphipodes talitridae) females into functional neo-males by grafting of androgen glands before the casting of first external sex differentiation (in French). CR Acad Sci Hebd Seances Acad Sci D 274:3449-3452 (1972b).
Guler Y, Short S, Kille P, Ford AT: Integrating field and laboratory evidence for environmental sex determination in the amphipod, Echinogammarus marinus. Mar Biol (2012), DOI: 10.1007/s00227-012-2042-2.

Lockwood APM: Aspects of the Physiology of Crustacea (Aberdeen University Press, Edinburgh and London, 1968).

Short S, Guler Y, Yang G, Kille P, Ford A: Paramyxean-microsporidian co-infection in amphipods: is the consensus that Microspordia can feminise their hosts presumptive? Int J Parasitol 42:683-691 (2012).

Werren JH, Windsor DM: Wolbachia infection frequencies in insects: evidence of a global equilibrium? Proc Biol Sci 267:1277-1285 (2000).

Yang G, Kille P, Ford AT: Infertility in a marine crustacean: have we been ignoring pollution impacts on male invertebrates? Aquat Toxicol 88:81-87 (2008)

Yang G, Short S, Kille P, Ford A: Microsporidia infections in the amphipod Echinogammarus marinus (Leach): suggestions of varying causal mechanisms to intersexuality. Mar Biol 158:461-470 (2011). 